\title{
Evidence of health care offered to women in situations of violence
}

\author{
Evidências acerca da atenção à saúde das mulheres em situação de violência
}

\author{
Evidencias acerca de la atención a la salud de las mujeres en situación de violencia
}

\author{
Laura Ferreira Cortes ${ }^{1}$, Jaqueline Arboit ${ }^{1}$, Stela Maris de Mello Padoin ${ }^{1}$, Cristiane Cardoso de Paula ${ }^{1}$
}

\begin{abstract}
Objective: to analyze the scientific evidence of enhancing and limiting factors of the care rendered to women in situation of violence. Methods: integrative review developed in Latin American and Caribbean Health Sciences database and Public Medline database. The corpus of the research included thirty studies. Results: the factors that enhance attention are related to services organization, conceptions and actions of professionals guided by strategies of communication and identification of violence. The limitating factores are conceptions of professionals grounded in traditional roles of genders, lack of training, protocols for the care and registration of cases, attitudes based on personal style and assistance focused in physical symptoms. Conclusion: the evidence points to the realization of screening and creation of protocols of assistance permeated by listening and guidelines directed to women ensuring the continuity of care network. There is a pressing need for investment in vocational training to provide of visibility to the theme in the health context.
\end{abstract}

Descriptors: Women Health; Violence Against Women; Delivery of Health Care.

Objetivo: analisar as evidências científicas de potencialidades e limites da atenção às mulheres em situação de violência. Métodos: revisão integrativa desenvolvida nas bases de dados Literatura Latino-Americana e do Caribe em Ciências da Saúde e Public Medline. 0 corpus de pesquisa incluiu trinta estudos. Resultados: os fatores potencializadores da atenção remetem à organização dos serviços, concepções e atuação dos profissionais pautadas em estratégias de comunicação e identificação da violência. Os limitadores são concepções dos profissionais alicerçadas em papéis tradicionais de gênero, inexistência de treinamento, de protocolos para o atendimento e registro dos casos, atitudes de cunho pessoal e assistência focada nos sintomas físicos. Conclusão: as evidências apontam para a realização de triagem e criação de protocolos de atendimento permeados pela escuta, orientações às mulheres e garantia da continuidade no cuidado em rede. É premente a necessidade de investimento na formação profissional proporcionando visibilidade do tema no âmbito da saúde.

Descritores: Saúde da Mulher; Violência Contra a Mulher; Assistência à Saúde.

Objetivo: analizar las evidencias científicas de potencialidades y límites de la atención a las mujeres en situaciones de violencia. Métodos: revisión integradora desarrollada en las bases de datos Literatura Latinoamericana y Ciencias de la Salud del Caribe y Public Medline. Investigación incluyó treinta estudios. Resultados: factores que impulsaron la atención se refieren a la organización de los servicios, concepciones y acciones de los profesionales guiadas en la comunicación e identificación de estrategias de violencia. Limitadores fueron concepciones de profesionales basadas en los roles tradicionales de género, falta de capacitación, protocolos para atención y registro de casos, actitudes personales y asistencia basada en síntomas físicos. Conclusión: evidencias apuntan para realización de clasificación y creación de protocolos de atención permeadas por escucha a las mujeres y directrices que garanticen continuidad de la red de atención. Hay necesidad urgente de inversión en la formación profesional que proporciona visibilidad del tema en la salud.

Descriptores: Salud de la Mujer; Violencia Contra la Mujer; Prestación de Atención de Salud.

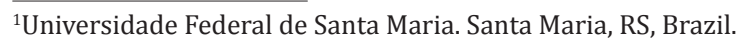

Corresponding author: Laura Ferreira Cortes

Av. Roraima, s/n, prédio 26, sala 1336, CEP: 97105-900. Cidade Universitária - Camobi. Santa Maria, RS, Brazil. E-mail: Iferreiracortes@ gmail.com 


\section{Introduction}

Violence against women, present in history since the dawn of civilization, is now defined as a public health problem due to its global epidemiological magnitude and impact on the lives of women and their families. Research conducted worldwide give the dimension of the problem: between $10.0 \%$ and $64.0 \%$ of women report to have been subjected to physical violence by intimate partners at some point in their lives $^{(1)}$.

Violence against women has recently began to be discussed as a problem that requires a confrontation that pervades the construction of conceptual and methodological elements as well as the implementation of singular public policies ${ }^{(2)}$. This type of violence is defined as any act or omission ruled on gender that causes death, injury or suffering of mental, sexual or psychological nature to women, whether in the public or private sphere ${ }^{(3)}$.

Violence against women is a social and multifaceted phenomenon, one of the extreme forms of manifestation of gender inequality that results from the asymmetry of power between men and women translated into relations of power and domination. Because violence influences the way women live, get ill and die, the health sector is the privileged locus for identification, assistance, reception and referral of women in situations of violence ${ }^{(4-5)}$.

Live without violence is a universal right. In order to implement this right, woman and their needs are an essential starting point. In this sense, the health care of women and the interaction between health professionals must transcend the ascription of a service and aim at solving the needs and their demands guided by strategies that enable women's empowerment. Health services are part of the service network and, therefore, professionals share responsibility in this process $^{(6)}$.

Important difficulties in the development of assistance are still present despite its importance. Many women that seek care in health services, due to direct or indirect injuries related to violence, often meet untrained professionals who have difficulty in detecting such situations ${ }^{(7)}$. Uncertainty about how to proceed in those cases can be attributed to academic training, since social problems such as violence contradict what is traditionally learned, the biomedical rationality of diagnosis and treatments ${ }^{(4,8)}$.

In this context, there is an apparent invisibility of violence on health services, because, in fact, professionals detect cases of violence, including doctors and nurses, recognize the problem, and most have positive attitudes of care, although they have difficulties in recognizing this as a health problem ${ }^{(8)}$. It is believed, thus, that building evidence regarding the factors enhancing and limiting the care offered to women in situations of violence can contribute to the development of strategies to identify situations of violence, promotion, protection and support for women. Thus, the present study raises the question "What evidence exists of enhancing and limiting factors of the care offered to women in situations of violence?" and to answer this question the scientific evidence of enhancing and limiting factors of care rendered to women in situations of violence were analized.

\section{Method}

This study is an integrative review of literature performed to gather and synthesize results of research on a specific topic or issue in a systematic and orderly manner. This type of review includes the analysis and synthesis of multiple studies published and provides general conclusions about a particular area of study ${ }^{(9)}$.

For the operationalization of this review the following steps were taken ${ }^{(9)}: 1$ ) Identification of the theme: health care for women in situations of violence; 2) Selection of the research question: "What evidence exists of enhancing and limiting factors of care offered to women in situations of violence?"; 3) Establishment of inclusion criteria: research paper on the topic, available online in full-length and preferably free, in 
English, Portuguese or Spanish; and published in the the time frame from 1994 to 2014, since the starting point is sustained by the Inter-American Convention on the Prevention, Punishment and Eradication of Violence against Women; and exclusion of articles without summary or incomplete in the database; 4. Definition of the information to be extracted: reference, year, origin, purpose, approach, subjects, key findings, and level of evidence; 5. Evaluation of the evidence and analysis (categorization): the analysis of the extracted data was performed in a descriptive way, enabling the evaluation of evidence according to seven levels ${ }^{(10)} ; 6$. Discussion and presentation of the synthesis of knowledge evidenced in the analyzed articles.

The classification of evidence considered the following levels of evidence: Level I- evidence from systematic review or meta-analysis of randomized controlled clinical trials or derived from clinical guidelines based on systematic reviews of randomized controlled clinical trials; level II- evidence derived from at least one randomized controlled well-designed clinical trial; level III- evidence from well-designed clinical trials without randomization; level IVevidence from cohort and well-designed case-control studies; level V- evidence from systematic review of descriptive and qualitative studies; level VI- evidence derived from a single descriptive or qualitative study; level VII- evidence from opinion of authorities and/or reports from committees of experts ${ }^{(10)}$.

Literature review was conducted in May 2015 by two researchers independently in the electronic databases Latin American and Caribbean Health Sciences (LILACS) and Public Medline (PubMed).

Controlled descriptors extracted from Descriptors in Health Sciences (DeHS) were used for the search in LILACS database, namely, "domestic violence" or "battered women" and "health care" or "health services for women" resulting in 69 studies. Sixty-six studies remained ater selecting specifically the pre-established time frame, and after excluding articles without summary, reflections and reports, 29 studies remained. After reading these articles in fulllength and after the thematic cut-off, eight studies from LILACS database were selected to compose the sample of the present review.

The Medical Subject Headings (MeSH Terms) "battered women" and "health services" used in the PubMed database and 692 studies were initially found. After applying the filter of time frame, 690 studies remained. After the idiomatic cut and after eliminating articles without sumaries, 571 articles remained. After exclusion of articles not available in full-length, 88 studies remained. With exclusion of reflections, reviews, reports and repetitions, 72 articles remained. These were read in full-length and after and after the thematic cut-off, 22 studies were selected from the PubMed database and these compose the sample of the present review.

Thus, after complying with the inclusion and exclusion criteria, the final sample consisted of 30 articles. In order to minimize possible measurement bias of studies (misinterpretation of results and design), two researchers carefully read the articles and filled, independently from each other, the instrument of data extraction and these were subsequently compared. In cases of divergences regarding the evaluation of the study, the researchers discussed the differences until reaching a consensus.

\section{Results}

The characterization of the articles revealed a predominance of studies carried out in Brazil, with ten studies (33.3\%), followed by USA with five studies (16.7\%), Spain with two studies (6.6\%) and Belgium, Chile, Ethiopia, Lebanon, India, Israel, South Africa, Bangladesh, Colombia, Kenya and Sweden with one study $(3.3 \%)$.

The temporal distribution of scientific literature was grouped in periods of four years and the period 2006-2009 showed the highest production rate with 12 studies (40.0\%), followed by the four-year period 1998-2001 with 2 studies (6.7\%), 2002-2005 with 
5 studies (16.7\%) and 2010-2014 with 11 studies (36.7\%). The quantitative methodological approach prevailed, it was presente in 17 studies (56.7\%), followed by qualitative approach in 9 studies (30\%), and both quantitative and qualitative in 4 studies (13.3\%). Studies on level of evidence 6 predominated with 28 studies (93.3\%) followed by studies with level of evidence 2 and 4, both with one study each (3.6\%).

The studies $(\mathrm{n}=30)$ were classified by reference, objective, design and main results. Data analysis enabled the identification of enhancing (Figure 1) and limiting (Figure 2) factors for the health care of women in situations of violence in the health services.

\begin{tabular}{|c|c|}
\hline \multicolumn{2}{|r|}{ Enhancing factors } \\
\hline 1. Organization of services & $\begin{array}{l}\text { Referrals to referenced services in articulated network }{ }^{(11)} \\
\text { Care continuity } \\
\text { Reception and bond with the team } \\
\text { Shared definition of discharge }{ }^{(13)} \\
\text { Changes in the structuring and provision of the service }{ }^{(15)} \\
\text { Work in multidisciplinary team }{ }^{(15)} \\
\text { Liaison with the legal department }{ }^{(14)} \text { and social services }{ }^{(13,16)} \\
\text { Comprehensive programs and group meetings }{ }^{(17-18)} \\
\text { Existence of specialized professionals } \\
\text { Prenatal care quality }\end{array}$ \\
\hline 2. Conceptions and actions of professionals & $\begin{array}{l}\text { Conception that violence is health care object }{ }^{(22,12,15)} \\
\text { Desire of professionals to be helpful and supportive }{ }^{(22)} \\
\text { Communication strategies with empathy, sensitivity } y^{(16,14,23)}, \text { reception }^{(14)} \text {, counseling, } \\
\text { listening, safety, information on available legal ressources } \\
\text { choices and empowering of women }{ }^{(19)} \\
\text { Confidential approach, emotional support, good professional-woman relationship }{ }^{(12,24)} \\
\text { Comprehensive explanations } \\
\text { Respect for life history } \\
\text { Intervention in community and social change }{ }^{(12)} \\
\text { Assistance to social and legal needs } \\
(12,17)\end{array}$ \\
\hline 3. Identification of violence & $\begin{array}{l}\text { Revelation by the woman }^{(26)} \\
\text { Realization of screening }{ }^{(12,19,25,27-28)} \\
\text { Inaccurate observation of symptoms and questions about personal relationships and } \\
\text { violence }^{(19)} \\
\text { Enough time to address and inclusion of the subject in professional training }{ }^{(25)}\end{array}$ \\
\hline
\end{tabular}

Figure 1 - Major enhancing factors for the health care of women in situations of violence according to scientific evidence 


\begin{tabular}{|c|c|}
\hline \multicolumn{2}{|r|}{ Limiting factors } \\
\hline 1. Organization of services & $\begin{array}{l}\text { High waiting time for receiving } \text { care }^{(24)} \\
\text { Lack of education/training } \\
\text { Lack of protocols and records of care } \\
\text { Lack of adequate facilities to offer care }{ }^{(29)}\end{array}$ \\
\hline 2. Conceptions and actions of professionals & $\begin{array}{l}\text { Blame and judgment of women } \\
\text { Negative feelings and difficulties to approach the subject } \\
\text { Misinformation about specialized services }{ }^{(13)} \\
\text { Limited time of professionals }{ }^{(15,19,22-29)} \\
\text { Lack of registration and invisibility of violence }{ }^{(15,25,31-35)} \\
\text { Personal attitudes and not technical-scientific attitudes } \\
\text { Assistance focused on symptoms and lesions }{ }^{(15,36)}\end{array}$ \\
\hline 3. Components of the violence itself & $\begin{array}{l}\text { Little awareness of women about the violence suffered } \\
\text { Difficulties of comprehension of guidelines by women } \\
\text { Private and domestic nature of violence against women } \\
\text { Pris,36-37) }\end{array}$ \\
\hline
\end{tabular}

Figure 2 - Main limiting factors for the health care of women in situations of violence according to the scientific evidence

\section{Discussion}

Factors related to the organization of services stand out as enhancing for the health care of women. Evidence of referral with higher promptness to reference services was observed, conforming an assistance in integrated and well-articulated network ${ }^{(11)}$. Thus, the continuity of care ${ }^{(12-13,31)}$ and definition of discharges shared between staff and users is considered decisive, making the service to remain open to the possibility of return of the women $^{(13)}$.

Some studies show that the bond with the team permeated by care and supervision after the end of the treatment ${ }^{(13-14)}$ as well as the ability of professionals to engage in changes of structure and provision of service are positive points. Moreover, the work in a multidisciplinary team, which is beyond the physiciancentered model and the individual consultation ${ }^{(15)}$ interconnected with legal professionals ${ }^{(13)}$ and social care $^{(13,16)}$ qualifies the access for these women ${ }^{(13)}$. There is potential when specialized agencies are equipped with appropriate knowledge and skills ${ }^{(20)}$ and when there are experts in family issues ${ }^{(19)}$.

In addition, comprehensive programs covering participation in group meetings ${ }^{(17-18)}$ are importante because when women share with each other their experiences of violence is most likely they feel supported and this facilitates the development of communication and problem solving skills $^{(18)}$. A study with persons who consult women in situations of violence ${ }^{(17)}$ suggests improvements in assistance programs when it comes to offering opportunities of training and development of a trade, including the help in legal requirements, social assistance, housing or employment ${ }^{(12,17)}$.

Enhancing factors are also related to conceptions of professionals guided by the understanding that violence should be treated as an object of health care $^{(12,22)}$ and their actions, based on the desire of professionals to be helpful and supportive to women in distress $^{(22)}$ and avoiding judgements ${ }^{(24)}$. Studies show that professional communication strategies can have a positive impact when permeated by empathy, sensitivity ${ }^{(14,16,23)}$, advice, listening, assurance of safety and when information about legal resources are made available ${ }^{(12,16,19-20)}$, respecting the rights and choices of women ${ }^{(19)}$. Also when it is permeated by confidentiality, emotional support between professional and women ${ }^{(12,24)}$, when the explanations are understandable ${ }^{(25)}$ and when there is respect for 
the history of women's lives, which carries intense suffering, and giving credibility to their statements on violence $^{(13)}$. The preservation of the autonomy enables women to perform changes in their lives ${ }^{(12)}$.

The possibilities of identifying a woman who suffered violence are greater when the health professional creates opportunities for open discussion, facilitating women to share their experiences and psychosocial issues such as stress ${ }^{(16)}$. Adoption of intervention strategies at community level, providing social change, like campaigns in the community and in the media, especially in rural areas where privacy and confidentiality are highly valued in the family, was considered a positive aspect ${ }^{(12)}$. Furthermore, attention is enhanced when the woman reveals the violence to the care provider, which allows intervention from specialized services. A study shows that women who received health service interventions specific for their cases were nearly three times more likely to report the breakdown of the relationship compared to women who did not receive such assistance. This fact is linked to improving the health of these women ${ }^{(26)}$. Equally important are the support services that emphasize empowerment ${ }^{(20)}$ and professional commitment to the promotion of women's rights and well-being ${ }^{(19)}$.

A study shows that primary care physicians demonstrate greater self-efficacy and success on the care of women suggesting greater sensibility and personal awareness of these professionals, and this could be attributed to the greater involvement with the situation because they know the women for some time ${ }^{(23)}$. For the nursing staff, the night shift was positive, allowing the nurse to devote more time to reception and consultation ${ }^{(14)}$. The association with high quality of prenatal care is also a positive factor $^{(20-21)}$.

Other factors that enhance the identification of violence and consequently the health care are realization of screening ${ }^{(12,19,25,27-29)}$; universal screening for violence in clinical settings, especially performed by nursing professionals ${ }^{(27)}$; direct screening $(19,29)$; screening and interventions for women who suffer psychological violence, since that precedes the physical abuse which may contribute to the primary prevention of physical injury ${ }^{(28)}$. A study highlights that the consequences of violence committed by the partner on the physical health of women allow health professionals to obtain better insight into the problem, facilitating the identification of services where women can be assisted for treatment. According to this evidence, women who have suffered three types of violence, physical, psychological and sexual, are more likely to suffer from a chronic disease, and this facilitates the identification of $\operatorname{cases}^{(38)}$.

Medical professionals of primary care refer to observe imprecise symptoms such as body aches, abdominal aches, headache, dizziness, insomnia, loss of appetite and even small changes in the body language of a user that may indicate something she wants to reveal that demands more privacy. In order to identify, professionals use strategies such as questions about life and personal relationships of women, trying to assess the situation based on this, and in some cases they make direct questions about violence $^{(19)}$. Noteworthy, a study reports that the use of the Spanish instrument Women Abuse Screening Tool-WAST was highly reliable, since it was able to discriminate between abused and not abused women ${ }^{(39)}$. In addition, the health professional must have enough time to address the issue and this needs to be present in vocational training ${ }^{(25,29)}$.

The limiting factors for the health care of women are related to the components of the violence itself linked to low awareness of women about the violence suffered ${ }^{(32)}$ and domestic and private nature of violence against women, which contributes to reject it as a target of assistance ${ }^{(15,36-37)}$. Professionals report that there are difficulties in understanding the guidance provided to women ${ }^{(15)}$.

The conceptions and actions of professionals restricted the attention when based in blame and judgment of the women by professionals ${ }^{(12-13,15,19,24,30)}$ as well negative feelings by professionals when dealing with this issue $e^{(13,15,19,22-23,30)}$ and inability to 
approach women, discuss, manage and refer cases of domestic violence committed by partners ${ }^{(29)}$. There is no information about the existence of specialized health services ${ }^{(13)}$, limited time of professionals and isolated consultations ${ }^{(15-16,19,29)}$ restricted to clinical detection of violence that mainly depends on the presence of physical and psychological trauma ${ }^{(29)}$. This implies cases of lack of registration, reflecting the invisibility of violence in the services ${ }^{(15,25,31-35)}$.

Some professionals, particularly primary care, say they have knowledge of situations about violence in their communities. However, according to them, there is a distance between becoming aware of those situations and recognizing them as concerning assistance and come to intervene. Silence is seen as a problem only coming from women and it is not associated to responsibility of the professional as well. In many cases, the team keeps neglecting the reason of the problem, which causes the persistence of physical, psychological and social damage and the repeated search for professional services. In many cases when the professional opted to intervene, he sees his action as personal or even an emotional statement, and not professional. They consider such intervention as uncomfortable and ineffective ${ }^{(15)}$ by not recognizeing any technical-scientific quality in this action. Thus, the professional often searchs for the most rapid means, as the medicalization and religious resources, which avoid involvement with problems that are so painful for women and so complex for professional practice ${ }^{(40)}$, limited to the clinical approach ${ }^{(36)}$.

The organization of services is another factor that limits the attention, which is evidenced by the long waiting time for care in health services ${ }^{(24)}$, absence of specialized care facilities ${ }^{(29)}$, lack of specific training about violence ${ }^{(13,15)}$, which results in difficulties to approach the subject ${ }^{(15-16,29)}$. Professionals assigned loss of motivation and many limits to their operations, which associate the large volume of services and the profile of users that expect to solve their problems quickly, while the team seeks to effect a routine not only of healing but also prevention and health promotion. This undermines the implementation of new protocols, including assistance to cases of violence $^{(1)}$.

Thus, structural difficulties and essentially curative demand create barriers for professionals to promote changes in the model of care $^{(15,36)}$ as well as promotes absence of health professionals in services $^{(40)}$, difficulties to sensitize other professionals (not linked to specialized services) and difficulties to make the follow up of women, especially in basic emergency rooms and health units, because these search for different services ${ }^{(13)}$. Other factors that influence negatively: little institutionalization of policies and programs, accessibility and availability of services, as well lack of knowledge of women about the existence of those institutions ${ }^{(20,35)}$.

The contributions of this study point to the identification of violence as a starting point for intervention. Therefore, questions of life and personal relationships of women can be used in the approach. On the other hand, there is a need for commitment of health professionals, to understand violence as a grievance inherent to health and that integrate professional practice, requiring multiprofessional and intersectoral coordination.

\section{Conclusion}

Considering that violence against women is a public health issue, the evaluation of evidence about the factors enhancing and limitating the health care rendered to women in situations of violence pointed to the urgency for including the issue in government priority agendas and health management agendas, in order to create an institutional culture that provides support to services and health professionals to perceive the problem. In order to achieve this, investment in vocational training by the academy is indispensable. This would provide visibility to the theme as well as learning strategies for the humanized, committed and multiprofessional networking.

The study indicates that the conceptions of 
professionals grounded in traditional gender roles constitute an obstacle to work with women. There is a need to invest in instrumentalisation of workers, one that has the gender issue as transversal, and this would increase the possibilities of identifying cases of violence and reception of women.

The screening strategies by health professionals, as well as host and care protocols are another aspect to be included in the dynamics of health work, besides the possibility of transfer this woman to other services that integrate the network of coping with this type of violence. The invisibility of violence against women points to the urgency of investments in reporting of cases in order to learn the real dimension of the problem, especially in countries like Brazil that have specific legislation for mandatory report.

Evidences also indicate that there are possibilities of working along with communities in the prevention of violence, starting from the recognition of this as an abuse of human rights. In this sense, acting in health becomes a powerful factor because professionals are often inserted in loco in the territory where these women are allocated, possibilitating the development of strategies of communication and approach that contribute to the promotion of equitable relations between women and men.

It is noteworthy that the studies included in this review represent only part of the multitude of literature produced on the topic. However, their contribution is in the deepening of the identification of evidence about the studied object.

\section{Collaborations}

Cortes LF and Arboit J contributed to the conception and design, analysis and data interpretation, writing of the article and final approval of the version to be published. Padoin SMM and Paula CC contributed to the relevant critical review of the intellectual content and final approval of the version to be published.

\section{References}

1. Organização Pan-americana de Saúde (OPS). Informe mundial sobre la violencia y la salud: resumen. Washington, DC(USA): Organização Pan-americana de Saúde; 2002.

2. Villela WV, Vianna LAC, Lima LFP, Sala DCP, Vieira TF, Vieira ML, et al. Ambiguidades e contradições no atendimento de mulheres que sofrem violência. Saúde Soc. 2011; 20(1):113-23.

3. Brasil.10 anos da adoção da Convenção Interamericana para Prevenir, Punir e Erradicar a Violência contra a Mulher. Convenção de Belém do Pará/Agende Ações em Gênero Cidadania e Desenvolvimento. Brasília: AGENDE; 2004.

4. Guedes RN, Silva ATMC, Fonseca RMGS. A violência de gênero e o processo saúde-doença das mulheres. Esc Anna Nery. 2009; 13(3):625-31.

5. Chaves OBBM, França ISX, Souza FS, Oliveira MG, Leite CCS. Sexual violence against women: nurses' practice. Rev Rene. 2015; 16(2):210-7.

6. Vieira LB, Padoin SMM, Sousa IEO, Paula CC, Terra MG. Necessidades assistenciais de mulheres que denunciam na delegacia de polícia a vivência da violência. Aquichan. 2013; 13(2):197-205.

7. Ribeiro CG, Coutinho MLL. Representações sociais de mulheres vítimas de violência doméstica na cidade de João Pessoa-PB. Psicol Saúde. 2011; 3(1):52-9.

8. Vieira EM, Ford NJ, Ferran FG, Almeida AM, Daltoso $\mathrm{D}$, Santos MA. The response to gender violence among Brazilian health care professionals. Ciênc Saúde Coletiva. 2013; 18(3):681-90.

9. Mendes KDS, Silveira RCCP, Galvão CM. Revisão integrativa: método de pesquisa para a incorporação de evidências na saúde e na enfermagem. Texto Contexto Enferm. 2008; 17(4):758-64.

10. Melnyk BM, Fineout-Overholt E. Making the case for evidence-based practice. In: Melnyk BM, Fineout-Overholt E. Evidence-based practice in nursing \& healthcare: a guide to best practice. Philadelphia: Lippincot Williams \& Wilkins; 2011. p.3-24.

11. Vertamatti MAF, Abreu LC de, Drezett J, Barbosa CP. Time lapsed between sexual aggression and arrival at the brazilian health service. J Hum Growth Dev. 2013; 23(1):46-51. 
12. Usta J, Antoun J, Ambuel B, Khawaja M. Involving the health care system in domestic violence: what women want. Ann Fam Med. 2012; 10(3):213-20.

13. Oliveira EM, Barbosa RM, Moura AAVM, Kossel KV, Morelli K, Botelho LFF, et al. The services for women victims of sexual violence: a qualitatif study. Rev Saúde Pública. 2005; 39(3):376-82.

14. Reis MJ, Lopes MH, Higa R, Bedone AJ. Nursing care of women who suffered sexual violence. Rev Latino-am Enfermagem. 2010; 18(4):740-7.

15. Kiss LB, Schraiber LB. Temas médico-sociais e a intervenção em saúde: a violência contra mulheres no discurso dos profissionais. Ciênc Saúde Coletiva. 2011; 16(3):1943-52.

16. Rhodes KV, Frankel RM, Levinthal N, Prenoveau E, Bailey J, levinson W. "You're not a victim of domestic violence, are you?" Provider patient communication about domestic violence. Ann Intern Med. 2007; 147(9):620-7.

17. Aguirre PD, Félix CS, Ma. PDG, Garrido CC, Mundaca Ll, Watt MH, et al. Estrés postraumático en mujeres víctimas de violencia doméstica. Rev Chil Neuro-Psiquiat. 2010; 48(2):114-22.

18. Sikkema KJ, Neufeld SA, Hansen NB, Mohlahlane R, Van Rensburg MJ, et al. Integrating HIV prevention into services for abused women in South Africa. AIDS Behav. 2010; 14(2):431-9.

19. Chibber KS, Krishnan S, Minkler M. Physician practices in response to intimate partner violence in southern India: insights from a qualitative study. Women's Health. 2011; 51(2):168-85.

20. Abeya SG, Afework MF, Yalew AW. Intimate partner violence against women in west Ethiopia: a qualitative study on attitudes, woman's response, and suggested measures as perceived by community members. Reprod Health. 2012; 20:9-14.

21. Viellas EF, Gama SG, Carvalho ML, Pinto LW. Factors associated with physical aggression in pregnant women and adverse outcomes for the newborn. J Pediatr. 2013; 89(1):83-90.

22. Soares GS. Health professionals and legal abortion in Brazil: challenges, conflicts, and Meanings. Cad Saúde Pública. 2003; 19(Supl 2):399-406.
23. Rabin S, Kahan E, Zalewsky S, Rabin B, Herz M, Mehudar 0 , et al. Primary care physicians' attitudes to battered women and feelings of selfcompetence regarding their care. Isr Med Assoc J. 2000; 2(10):753-7.

24. Naved RT, Rimi NA, Jahan S, Lindmark G. Paramedic-conducted mental health counselling for abused women in rural Bangladesh: an evaluation from the perspective of participants. J Health Popul Nutr. 2009; 27(4):477-91.

25. Rodriguez M, Shoultz J, Richardson E. Intimate partner violence screening and pregnant Latinas. Violence Vict. 2009; 24(4):520-32.

26. McCloskey LA, Lichter E, Williams C, Gerber M, Wittenberg E, Ganz M. Assessing intimate partner violence in health care settings leads to women's receipt of interventions and improved health. Public Health Rep. 2006; 121(4):435-44.

27. Coker AL, Flerx VC, Smith PH, Whitaker DJ, Fadden $\mathrm{MK}$, et al. Partner violence screening in rural health care clinics. Am J Public Health. 2007; 97(7):1319-25.

28. Coker AL, Flerx VC, Smith PH, Whitaker DJ, Fadden $\mathrm{MK}$, et al. Intimate partner violence incidence and continuation in a primary care screening program. Am J Epidemiol. 2007; 165(7):821-27.

29. Roelens K, Verstraelen $H$, Van Egmond $K$, Temmerman M. A knowledge, attitudes, and practice survey among obstetriciangynaecologists on intimate partner violence in Flanders, Belgium. BMC Public Health. [Internet]. 2006 [cited 2015 Aug. 13]; 6:238. Available from:http://www.biomedcentral.com/14712458/6/238

30. Pratt-Eriksson D, Bergbom I, Lyckhage ED. Don't ask don't tell: Battered women living in Sweden encounter with healthcare personnel and their experience of the care given. Int J Qual Stud Health Well-being. 2014; 9:1-7.

31. Ramos CRA, Medicci VPG, Puccia MIR. Mulheres vitimadas sexualmente - perfil sociodemográfico e análise do atendimento em um centro de referência. Rev Inst Invest Cienc Salud. 2009; 27(1):22-7. 
32. Schraiber LB, D'Oliveira AF, Couto MT, Hanada H, Kiss LB, Durand JG, et al. Violence against women attending public health services in the metropolitan area of São Paulo, Brazil. Rev Saúde Pública. 2007; 41(3):359-67.

33. Muslera-Canclini E, Natal C, García V, FernándezMuñoz P. Description of registration of episodes of gender violence in medical records in the Principality of Asturias, Spain. Gac Sanit. 2009; 23(6):558-61.

34. Pallitto CC, O'Campo P. The relationship between intimate partner violence and unintended pregnancy: analysis of a national sample from Colombia. Int Fam Plan Perspect. 2004; 30(4):16573.

35. Ynoub RC. Caracterización de los servicios de atención en violencia familiar del área metropolitana de Buenos Aires, Argentina. Cad Saúde Pública. 1998; 14(1):71-83.
36. Silva IV. Violence against woman: clients of emergency care units in Salvador. Cad Saúde Pública. 2003; 19(Suppl 2):263-72.

37. Odero M, Hatcher AM, Bryant C, Onono M, Romito P, Bukusi EA, et al. Responses to and Resources for Intimate Partner Violence: Qualitative Findings from Women, Men, and Service Providers in Rural Kenya. J Interpers Violence. 2014; 29(5):783-805.

38. Ruiz-Pérez I, Plazaola-Castaño J, Del Río-Lozano M. Physical health consequences of intimate partner violence in Spanish women. Eur J Public Health. 2007; 17(5):437-43.

39. Fogarty CT, Brown JB. Screening for abuse in Spanish-speaking women. J Am Board Fam Med. 2002; 15(2):101-11.

40. Almeida APF, Sousa ER, Fortes S, Minayo MCS. Dor crônica e violência doméstica: estudo qualitativo com mulheres que frequentam um serviço especializado de saúde. Rev Bras Saúde Matern Infant. 2008; 8(1):83-91. 